\title{
Combat Sports Injuries in Well-Trained Athletes during African Games 2015 in Brazzaville, Congo
}

\author{
Massamba Miabaou Didace1, Moulongo Jean Georges André2, \\ Kimpamboudi Matondo Aubierge Victoire ${ }^{3}$, Massamba Cola Steven Ismaël Justy², \\ Massamba Alphonse ${ }^{2,4^{*}}$
}

\author{
${ }^{1}$ Surgery Department, Faculty of Health Sciences, Marien Ngouabi University, Brazzaville, Congo \\ ${ }^{2}$ Martial Arts and Combat Sports Research Unit, Fundamental and Applied Human Movement Sciences Laboratory, Higher \\ Institute of Physical Education and Sports, Marien Ngouabi University, Brazzaville, Congo \\ ${ }^{3}$ Surgery Department, Makélékélé's Hospital, Brazzaville, Congo \\ ${ }^{4}$ Biomechanics and Motion Analysis Laboratory, Higher Institute of Physical Education and Sports, Marien Ngouabi \\ University, Brazzaville, Congo \\ Email: *mboya53@gmail.com
}

How to cite this paper: Didace, M. M., André, M. J. G., Victoire, K. M. A., Justy, M. C. S. I., \& Alphonse, M. (2017). Combat Sports Injuries in Well-Trained Athletes during African Games 2015 in Brazzaville, Congo. Advances in Physical Education, 7, 274-285.

https://doi.org/10.4236/ape.2017.73022

Received: May 18, 2017

Accepted: August 11, 2017

Published: August 14, 2017

Copyright $\odot 2017$ by authors and Scientific Research Publishing Inc. This work is licensed under the Creative Commons Attribution International License (CC BY 4.0).

http://creativecommons.org/licenses/by/4.0/

\begin{abstract}
The aim of this study was to analyze the epidemiology and distribution of combat sports injuries during African Games 2015. A retrospective study was conducted from November 2016 to February 2017, including all adult patients aged consulted by doctor during combat or admitted to emergency medical sport unit of complex sporting of these Games. The data collected were sex, time and day of consulting or admission, injury risk, types, location and causes of injuries. During these African Games, an average injury frequency of about $78.6 \%$ has been observed. Contusions $(n=104)$, sprains and luxations $(n=43)$, fractures ( $\mathrm{n}=40)$ and wounds $(\mathrm{n}=12)$ were the main injuries observed among 187 athletes. The lower extremities were more frequently affected than the upper extremities (150 cases versus 78 cases). In conclusion, the present study provides the latest knowledge on the frequency and characteristics injuries in combat sports. Injuries are different according to sport in their mechanisms and injury distribution. During African competition and training session, the evaluation and prevention of these factors could decrease the occurrence of such injuries.
\end{abstract}

\section{Keywords}

Combat Sports, African Games, Injuries 


\section{Introduction}

Combat sports refer to a group of individual sports that are very relevant to the world sportive scenario. Altogether, the Olympic disciplines of combat sports (i.e. judo, wrestling, taekwondo and boxing) account for almost $25 \%$ of total medals disciplined in the Olympic Games (Gutiérrez-Garcia, Pérez Gutiérez, \& Svinoh, 2010). Each specific combat sport has a unique combination of rules that confers singular characteristics to each one (e.g., grappling-based techniques or striking-based techniques; scoring system; number of rounds; recovery time between rounds; time duration of each round; distribution of gender; organization in weight divisions) (Poceco, Ruedl, Stankovic et al., 2013; Harmer, 2010). Despite those differences, studies have shown that most combat sports can be characterized as high-intensity, intermittent sports (Campos, Bertuzzi, Dourado, et al., 2012; Artioli, Gualano, Franchini et al., 2009; Franchini, Del Vecchio, Matsushigue et al., 2011; Terbizan \& Selievold, 1996; Del Vecchio, Hirata, \& Franchini, 2011). Consequently, injury risk had been consistently high in these athletes (Kobayashi, Kanamura, Koshida et al., 2010), even if the International Olympic Committee initiated and developed the injury and illness surveillance system during the 2008 Beijing and 2012 London Olympics (Junge, Engebretsen, Mountjoy et al., 2009; Engebresten, Soligard, Steffen et al., 2013). In the literature, a few prospective and retrospective studies as well as case reports dealing with combat injuries are available (Souza, Monteiro, Del Vecchio et al., 2006; Green, Petrou, Fogarty-Hover et al., 2007; Pierantozzi \& Muroni, 2009). In example, Souza, Monteiro, Del Vecchio et al. (2006) reported frequency of $12.5 \%$ of injuries in Brazilian Judo Championship 2005, whereas Pierantozzi and Muroni (2009) noted percent of $8.1 \%$ of injuries during Italian Judo Championship 2008. However, to our knowledge, no data is available in African Games since 1965 to nowadays and the distribution on combat sports injuries during African Games 2015. Therefore, the aim of this study was to analyze the epidemiology and the distribution on combat sport injuries during African Games 2015.

\section{Methods}

The retrospective study included all the sportsmen practising the sports of combat having taken part in the African Games 2015 of Brazzaville, among the 12 sporting disciplines selected. However, we focus on the judo, boxing, taekwondo and wrestling. Of the 336 combat sports athletes, 238 were recruited consulted by a sporting doctor appointed by the medical commission of the Games or admitted with the medico-sporting urgencies of the sporting complex of Kintélé (Brazzaville), following a traumatism between 4 and 19 September 2015. Inclusion/exclusion criteria for subjects were: to be competitive amateur combat sports (boxing, judo, taekwondo, wrestling) in these African Games 2015; to be injured during round competition; no history of orthopedic, cardiovascular or metabolic disorders that may affect the subjects' ability to perform a high-intensity work six months before African Games 2015. The other collected data in- 
cluded/understood the mode of recourse (between or not addressed by the referee or the appointed doctor), nature, the seat and the type of assumption of responsibility of the lesions, and management of injuries in sporting medical emergencies.

According to Medical Subject Headings (MeSH), injuries are primarily defined as damage inflicted on the body as the direct or indirect result of an external force, with or without disruption of structural continuity. However, as a result of different designs of the reviewed literature, including prospective (Green, Petrou, Fogarty-Hover et al., 2007; Pierantozzi \& Muroni, 2009), as well as retrospective studies (James \& Pieter, 2003; Witkowski, Maslinski, Stefaniak et al., 2012), it was not possible to adopt a standardised definition, neither of injury, nor of the severity grade of injuries. In this study, an injury was defined as any physical complaint sustained by a competitor irrespective of the need for medical attention or time-loss from activities (Pierantozzi \& Muroni, 2009), or which caused an exclusion from sports-related activities for at least 4 days (Witkowski, Maslinski, Stefaniak et al., 2012).

After anonymization, the data were seized on Epi information 3.5.3 and treated after quality control and checking of coherence of the data. The average for the age as well as the standard deviation was calculated. For the qualitative variables, the frequency of distribution of the various variables was given. Chi square was used for comparing categorical parameters. All statistical analyses were performed using the Statistical Package for the Social Sciences (version 17.0; SPSS, Chicago, IL) at the Statistics Laboratory, Department of Applied Mathematics, Faculty of Sciences, Marien NGOUABI University. $P$ value $\leq 0.05$ defined statistical significance.

\section{Results}

Among the 238 patients, 187 of them (78.6\%) had been consulted by a doctor on the site of the combat (carpet of judo, taekwondo or fight; boxing ring for boxing). They were 81 judokas, 40 fighters, 25 boxers and 41 taekwondoists. The demographic data of all the patients are indicated in Table 1 . The others traumatized had been taken along to the medico-surgical urgencies by a doctor. The means of transport was a vehicle of help. The distance between the sites of the sporting meetings and the urgencies varied from $1 \mathrm{~km}$ to $12 \mathrm{~km}$. The majority of the consultations on the site took place Fridays, Saturdays and Sundays. As for the admissions with the urgencies, their office plurality reached finally week approximately $10.2 \%$ during the two weeks when the competitions related to the sports of combat proceeded.

The frequency of injuries associated to early production of lactate (cramps and muscular tiredness) rose with $73.3 \%(\mathrm{n}=137)$. For these subjects, massage with ozonised oils and oils enriched with bioperoxoil ${ }^{\circ}$ was used. The distribution of the injuries was different according to the sport (Table 2). The circumstances of injuries were different as function as sport: muscular fatigue in judo for $80.4 \%$ of cases, $74.9 \%$ of cases in wrestling, $65.2 \%$ of cases in taekwondo; muscular 
Table 1. Demographic characteristics of patients.

\begin{tabular}{|c|c|c|c|c|c|}
\hline Variable & $\begin{array}{l}\text { All patients } \\
(\mathrm{n}=238)\end{array}$ & $\begin{array}{l}\text { Judoists } \\
(\mathrm{n}=101)\end{array}$ & $\begin{array}{c}\text { Wrestlers } \\
(\mathrm{n}=50)\end{array}$ & $\begin{array}{l}\text { Boxers } \\
(\mathrm{n}=39)\end{array}$ & $\begin{array}{c}\text { Taekwondoists } \\
\quad(\mathrm{n}=48)\end{array}$ \\
\hline Age, mean (SD) & $24.6(1.8)$ & $25.2(1.7)$ & $24.8(2.3)$ & $25.1(1.5)$ & $23.4(1.8)$ \\
\hline \multicolumn{6}{|l|}{ Sex, n (\%) } \\
\hline Male & $173(72.7)$ & $68(67.3)$ & $32(64.0)$ & $39(100)$ & $34(70.8)$ \\
\hline Female & $65(27.3)$ & $33(32.7)$ & $18(36.0)$ & ---- & $14(29.2)$ \\
\hline \multicolumn{6}{|l|}{$\begin{array}{l}\text { Years of practice, } \\
\text { mean }(S D)\end{array}$} \\
\hline $5-7, \mathrm{n}(\%)$ & $47(19.7)$ & 13(12.9) & $12(24.0)$ & $6(15.4)$ & $16(33.3)$ \\
\hline $8-10, n(\%)$ & $149(62.6)$ & $71(70.3)$ & $35(70.0)$ & $21(53.8)$ & $22(45.8)$ \\
\hline$\geq 11, \mathrm{n}(\%)$ & $42(17.7)$ & $27(16.8)$ & $3(6.0)$ & $12(30.8)$ & $10(20.9)$ \\
\hline \multicolumn{6}{|c|}{ Scholar status, $\mathrm{n}(\%)$} \\
\hline Primary & $52(21,8)$ & $15(14.9)$ & $19(38.0)$ & $13(33.3)$ & $5(10.4)$ \\
\hline Secondary & $165(69.3)$ & $73(72.3)$ & $24(48.0)$ & $26(66.7)$ & $42(87.5)$ \\
\hline Student & $21(8.9)$ & $13(12.8)$ & $7(14.0)$ & ---- & $1(2.1)$ \\
\hline \multicolumn{6}{|c|}{ Alcohol intake, n (\%) } \\
\hline Drinker & $67(28.2)$ & $15(14.9)$ & $14(28.0)$ & $13(33.3)$ & $25(52.1)$ \\
\hline Former drinker & $73(30.7)$ & $42(41.6)$ & $8(16.0)$ & $11(28.2)$ & $12(25.0)$ \\
\hline Nondrinker & $98(41.1)$ & $44(43.5)$ & $28(56.0)$ & $15(38.5)$ & $11(22.9)$ \\
\hline \multicolumn{6}{|l|}{ Smoker, n (\%) } \\
\hline Current smoker & $21(8.8)$ & $5(5.0)$ & $2(4.0)$ & $3(7.7)$ & $11(22.9)$ \\
\hline Ex-smoker & $53(22.3)$ & $31(30.7)$ & $14(28.0)$ & $4(10.3)$ & $4(8.3)$ \\
\hline No smoker & $164(68.9)$ & $65(64.3)$ & $34(68.0)$ & $32(82.0)$ & $33(68.8)$ \\
\hline
\end{tabular}

Table 2. Distribution of injuries as function as sport and sex.

\begin{tabular}{ccccccc}
\hline Injuries & Sex & Judo & Boxing & Wrestling & Taekwondo & Variation (\%) \\
\hline Contusions & & & & & 17 & \\
Male & 61 & 13 & 17 & 14 & 17 & +9.3 \\
Female & 43 & 17 & -- & 16 & 10 & +6.2 \\
Fractures & & & & & & \\
Male & 31 & 4 & 11 & 5 & 11 & +9.6 \\
Female & 9 & 2 & -- & 1 & 6 & +0.3 \\
Sprains/Luxations & & & & & & \\
Male & 28 & 9 & 5 & 10 & 4 & +2.0 \\
Female & 15 & 5 & -- & 8 & 2 & +0.8 \\
\hline
\end{tabular}

elongations in wrestling ( $10.1 \%$ of cases); wounds (6.5\% of cases) in boxing. The distribution of other injuries $(\mathrm{n}=50)$ was by descending order: contusions $(\mathrm{n}=$ $61 \%-32 \%)$, fractures $(n=43 \%-26 \%)$, strains $(n=35 \%-7 \%)$, wounds $(n=7 \%$ $3 \%)$ and sprains $(\mathrm{n}=5 \%-3 \%)$. The distribution of these injuries according to the sex was homogeneous $(P=0.25)$ but, considering the risk of fracture compared with the other injuries, the men had a higher risk [OR $=2.18$; CI $95 \%$ ranging (1.05 - 5.34); $P=0.048]$.

The seat of the injuries prevailed with the upper limbs in $54 \%$ of the case $(\mathrm{n}=$ 109) followed lower limbs (39.1\% of the cases; $n=93)$. The other traumatisms 
sat on the level of the head and the neck.

The risk of attack of the upper limb was higher at men $[\mathrm{OR}=9.51(3.82$ 25.34)]; $P<0.0001)$ the lesions related to the lower limbs $(43 \%-25 \%)$, the head and the neck (35\% - 18\%) including 15 cervical attacks, 13 cranial traumatisms and wounds of the scalp, 4 traumatisms of the jaw. The attacks affecting the rachis sat on the level of the thorax $(7 \%-4 \%)$, the back and the limbs $(3 \%-2 \%)$, with type of contusion. The abdominal traumatisms, not very frequent $(n=12)$ were found on the level of the taekwondo, with type of simple contusion, without subjacent visceral lesion. A case of traumatism of the external genitals had been noted in a judoka man during a projection of the technique uchi-mata.

On the level of the upper limb (Table 3), the proximal injuries on the level of the shoulder (32\%) prevailed and of the elbow (21\%) the distal attacks of the upper limb were divided into: $18 \%$ of lesions of the front arm lever and the wrist $(\mathrm{n}=14)$ and $18 \%$ of traumatisms of the hand $(\mathrm{n}=14)$. This distribution was comparable between the men and the ladies. Concerning the shoulder, the prevalent fractures were those of the clavicle ( $46 \%$ of the cases, found in the taekwondo) and in $18 \%$ of the cases of the fractures of the end of superior of the humerus (case of the taekwondo). The other lesions were represented by simple injuries $(n=2)$ and acromioclavicular distorsions $(n=3)$. No luxation of shoulder had been detected. On the level of the elbow and the front arm lever or wrist, the fractures respectively accounted for $44 \%$ of the cases $(n=12)$ and $37 \%(n=$ $10)$. With regard to the front arm lever and the wrist, the other attacks were distorsions.

On the level of the lower limbs (Table 3), in contrast to the upper limbs the distribution of the injuries concerned, the distal part of the member, starting from the knee where $29 \%$ of the lesions $(n=10)$ concentrated.

The attacks of the foot added up $55 \%$ of the cases $(n=34)$, of the knee $(29 \%$ of

Table 3. Nature and distribution of injuries to a due level of upper limb and lower limb.

\begin{tabular}{ccccc}
\hline & Contusions & Fractures & Sprains/Luxations & Wounds \\
\hline Upper limb & 5 & 3 & 5 & 1 \\
Shoulder (n) & 12 & 7 & 11 & 4 \\
Elbow (n) & 10 & 8 & 9 & 3 \\
Wrist (n) & 27 & 18 & 25 & 8 \\
Total 1 & 3 & & & 1 \\
Lower limb & 10 & -- & -- & 2 \\
Hip (n) & 8 & 5 & 6 & 1 \\
Knee (n) & 13 & 3 & 4 & 1 \\
Leg (n) & 34 & 16 & 8 & 4 \\
Ankle (n) & 61 & 34 & 18 & 12 \\
Total 2 & & & 43 & \\
Total & 10 & & \\
\hline
\end{tabular}


the cases; $n=10$ ) or of ankle (38\%). Concerning the type of lesions of the lower limbs (Table 2), the contusions prevailed with $38 \%$ of the traumatisms of ankle and $(\mathrm{n}=10)$ and $29 \%$ of the traumatisms of the knee. At the cranial level, the traumatisms dominated. The wounds were rare $(n=4)$. The various types of fractures of the upper limb and the lower limb and their assumption of responsibility are indexed in Table 4. The assumption of responsibility of the patients was in the majority of the cases of the spontaneous type (93\% of the cases). Two orthopedic reductions under $\mathrm{Mé}^{\infty} \mathrm{a}^{\oplus}$ for fractures of the lower third of the two bones of the front armlever had been carried out with the urgencies, not allowing thus the resumption of the competition.

\section{Discussion}

The present study was initiated to identify the secondary traumatisms with the practice of the combat sports to the African Games 2015 of Brazzaville. The number of the athletes of combat sports did not cease increasing by 1965 (1rst African Games) to 2015 ( $11^{\text {th }}$ African Games). This rise had consequences in terms of specific accidentology and dealt with between 1965 and 2015. The medical commissions of different Games recorded an increase of $8.3 \%$ of the traumatisms related to the practice of the combat sports, varying from $7 \%$ in 1965 (judo and boxing) to $15.3 \%$ in 2015, bound mainly to the integration of the wrestling and the taekwondo and the participation of the ladies. Sprains, strains and contusions, usually of the knee, shoulder and fingers, were the most frequently reported injuries, whereas being thrown was the most common mechanism. The injury frequency during the two most recent Summer Olympic Games (SOG) of about $11.2 \%-12.3 \%$ is well in accordance with the average injury frequency of $11 \%$ for all sport disciplines together in the 2012 SOG (Junge, Engebretsen, Mountjoy et al., 2009; Engebresten, Soligard, Steffen et al., 2013). In comparison, taekwondo had the highest injury frequency with $39.1 \%$ during the London Games while in archery, canoe slalom and sprint, track cycling, rowing, shooting and equestrian sport less than $5 \%$ of athletes were injured

Table 4. Nature of the immobilization and the treatment of the fractures according to their location.

\begin{tabular}{|c|c|c|c|c|}
\hline Location of fracture & Type of immobilization & $\begin{array}{l}\text { Orthopedic reduction by General } \\
\text { Méopa }{ }^{\bullet} \text { anaesthesia }\end{array}$ & Osteosynthesis & Return urgencies \\
\hline Upper limbs $(n=18)$ & & $0 \quad 0$ & 0 & \\
\hline Clavicle & Claviclar rings & $0 \quad 0$ & 0 & 0 \\
\hline \multirow[t]{2}{*}{ Higher end of the humerus } & Dujarrier & -- & -- & 0 \\
\hline & Plaster during BABP & 07 & 2 & \\
\hline \multirow[t]{2}{*}{ Lower end of the humerus } & BABP & -- & -- & Pain under plaster \\
\hline & Dujarrier & 23 & 0 & 0 \\
\hline Front armlever, wrist & BABP, cuffs Syndactyly & $0 \quad 0$ & 0 & 0 \\
\hline \multirow[t]{2}{*}{ Finger (inch) } & Plastered gantelets & -- & -- & \\
\hline & & 01 & & \\
\hline \multirow{5}{*}{$\begin{array}{l}\text { Lower limbs }(\mathbf{n}=16) \\
\text { Inferior end of the femur } \\
\text { Leg } \\
\text { Toe }\end{array}$} & & (Arthroscopy) & & 0 \\
\hline & Cruro-pedal plaster Boots foundations of & $\begin{array}{ll}0 & 0\end{array}$ & 0 & Ablation of the plaster \\
\hline & concrete, cruro-pedal plaster & -- & $\begin{array}{l}0 \\
0\end{array}$ & 0 \\
\hline & Boots foundations of concrete, & $0 \quad 0$ & 0 & Repair of the plaster \\
\hline & & $\begin{array}{ll}0 & 0\end{array}$ & & \\
\hline
\end{tabular}


(Engebresten, Soligard, Steffen et al., 2013). Our frequency of injuries in taekwondo, equal to $17.2 \%$, is significantly higher $(\mathrm{p}=0.032)$. Compared with other Olympic combat sports, judo time loss injury frequency of $6 \%-9 \%$ during the last two SOGs was clearly lower than in taekwondo (16\% - 18\%) but slightly higher than in boxing $(4 \%-8 \%)$ and wrestling $(5 \%-6 \%)$, respectively (Junge, Engebretsen, Mountjoy et al., 2009; Engebresten, Soligard, Steffen et al., 2013). In this study, injuries' frequencies were higher, compared to other studies relating to judo (Barrault, Achou, \& Sorel, 1983), wrestling (Cynarski \& Kudlacz, 2008), boxing (Del Veccio \& Gonçalves, 2012) and taekwondo (Del Veccio \& Gonçalves, 2012). Many factors can explain these differences. Although nutrition, training level, hydration and weight cycling are considered important injury risk factors in combat sports (Boisseau, 2006; Agel, Ransone, Dick et al., 2007; Kordi, Maffulli, Wroble et al., 2009), specific research on martial arts is still very scarce (Kordi, Maffulli, Wroble et al., 2009). In example, a higher frequency of injuries and impairment of muscular function have been found in weight cycling judoists and among those undergoing rapid weight reductions before a competition compared with control groups of judo athletes (Poutreau, Ducher, Serbescu et al., 2007). Concerning massage, Brooks et al. (2005) found that manual massage to the forearm and hand after maximal exercise was associated with greater effect than non-massage on post-exercise power grip performances in healthy adults. Furthermore, Ogai et al. (2008) showed that sports massage was effective for decreasing perceived lower limb fatigue and muscle stiffness. Techniques like effleurage (stroking) and petrissage (kneading) are commonly used in sports massage to induce post-exercise intramuscular oedema resolution, by facilitating fluid movement and increasing circulation (Poutreau, et al., 2007). The ozonized oils have been widely studied in their chemical structure, in their pharmacology and toxicology and in their dermatologic compatibility (Travagli et al., 2011) giving guarantees on the perfect tolerability in dermatologic applications.

Moreover, even if bone injuries were not higher $(14.3 \% ; n=34)$ in this study, the higher risk in bone injuries due changes in bone metabolism has been referred as a consequence of weight cycling in combat sports studied. Nevertheless, the strength requirements and technical characteristics of different sports' practice may also be preventive factors for bone loss and bone-related injuries (Poutreau, Pelle, Collomp et al., 2006). Furthermore, it has been reported (RiveraBrown \& De Felix-Davila, 2012) that the fluid restriction practiced by many combat sport athletes when involved in weight loss processes (Artioli, Gualano, Francini et al., 2010), in conjunction with intense training in these sport in hot environments, resulted in serious dehydration, which might provoke heat-related injuries. Despite the described risks, most judo and wrestling athletes reduce their weight a short time before competition (Fabrini, Brito, Mendes et al., 2010; Brito, Castro Martins Roas, Souza Brito et al., 2012). In addition, the research results of recent years reinforce the assumption that psychological factors are involved in the development of combat sports injuries (Andersen \& Wil- 
liams, 1988; Vago, Casola, Lovecchio et al., 2013). The perceived similarity and control seem to directly contribute to the perceived risk of injury (Deroche, Stephan, Woodman et al., 2012).

Our results indicate also that the nature of the injuries observed is comparable with those of the literature. With the exception of the contusions and distortions, they are not seemed different according to studied sports of combat. Indeed, according to Cunningham (1996) and other authors the contusions are the wounds most common during the practice of the judo, karate and the taekwondo (Table 5).

The fractures come then, except in the study of Yard and Knox (Yard \& Knox, 2007), for which the fractures were prevalent. The distortions are described for the judo and the taekwondo, but are not noted for the wrestling, because of different organic mechanism. On the other hand, a study concerning the injuries which have occurred in the adults (on a troop of 93 judokas) at the time of a competition of judo in Sao Paolo (Souza \& Monteiro, 2006), highlighted a majority of distortions, contusions, ligamentar injuries, luxation's, but did not find fracturar injuries. Sterkowicz (1999) reports similar results in adult judokas. These differences between the disciplines are explained by techniques of different combat and training level. Indeed, the injuries are in connection with direct injuries in boxing and wrestling; on the other hand, with the judo, they are in connection with the falls, the techniques of throttling and keys of arm (Sterkowicz, 1999). The fractures are more frequent in athletes whose experiment of practice varies from 5 to 7 years and old of less than 22 years, because probably of the mechanisms of fall and of a different, charged out of water and less resistant osseous structure.

Table 5. Studies published on the injuries related to the practice of combat sports.

\begin{tabular}{|c|c|c|c|c|}
\hline Study & Present study & Sterkowicz & $\begin{array}{l}\text { Souza and } \\
\text { Monteiro }\end{array}$ & Cunningham \\
\hline Year of publication & 2017 & 2004 & 2006 & 1996 \\
\hline Population & Adult & Adult & Adult & Adult \\
\hline Sport & $\begin{array}{c}\text { Judo, lutte, } \\
\text { boxing, taekwondo }\end{array}$ & Judo & Judo & Arts martiaux \\
\hline Number & 238 & 320 & 93 & 1177 \\
\hline Mean age (years) & 24.6 & Not paid & 27.8 & 22.2 \\
\hline $\begin{array}{l}\text { Standard Deviation } \\
\text { (years) }\end{array}$ & 1.8 & Not paid & 1.7 & 0.2 \\
\hline Sex-ratio & 2.7 & Not paid & Not paid & -- \\
\hline Contusions (\%) & 25.6 & -- & 15.5 & 23.5 \\
\hline Sprains (\%) & 18.1 & 4.1 & 26.4 & 29.4 \\
\hline Wounds (\%) & $7-3$ & -- & -- & -- \\
\hline $\begin{array}{l}\text { Musculotendinous } \\
\text { injuries (\%) }\end{array}$ & 0 & -- & 12.7 & 5.9 \\
\hline Luxations (\%) & 18.1 & 1.9 & 9 & 11.8 \\
\hline Concussion (\%) & 0 & -- & -- & -- \\
\hline
\end{tabular}


This phenomenon, found in our study, is also described by Birrer and Halbrook (1988) in the taekwondo where the principal injuries the candidates correspond to not blocked attacks, because of their lack of anticipation and experiment.

Moreover, the nature of the injuries varied according to the sex. The women presented contusions rather, without statistically significant difference $(P=$ $0.067)$ and the men of the fractures significantly $(P=0.041)$. This tendency was found in the literature with, within the framework of injuries of sport in general, of the more significant of distortions and contusions, and less frequencies of fracture at the ladies (Pieter, 2005). In our study, the distribution of the injuries, according to parts' of the body injured, were comparable with that of Souza and Monteiro (2006) concerning the injuries of the judo. The organic attacks prevail on the upper limbs, but without significant difference compared to those found on the level of the lower limbs (32.8\% versus $30.3 \%)$, indifferently of the sex. This fact can be explained for example to the judo through the mechanisms of the wounds (James \& Pieter, 2003): majority of mechanisms of projection by the adversary or during work on the ground for the female sex; at the men, the agripments prevail causing more frequent digital injuries, projections of or by their adversary (James \& Pieter, 2003). Lastly, according to Sterkowicz (1999), the proximal injuries of upper limb, in particular of the shoulder and the scapula are most frequent in the less tested and well-being trained judokas; they decrease at the candidate in combat sports according to the experiment and the type of practiced sport.

\section{Conclusion}

The present study provides the latest knowledge on the frequency and characteristics of injuries in combat sports during African Games 2015. The most found injuries are the contusions followed by the distortions. Their gravity remains weak. The factors of risk are represented by the training level, the nature of the sport and the sex. Consequently, comprehensive knowledge about the frequency of injury during combat sports and related risk factors represents an essential basis to develop effective strategies for injury prevention. Thus, the introduction of an ongoing injury surveillance system in different combat sports is of the utmost importance.

\section{References}

Agel, J., Ransone, J., Dick R. et al. (2007). Descriptive Epidemiology of Collegiate Men's Wrestling Injuries: National Collegiate Athletic Association Injury Surveillance System, 1988-1989 through 2003-2004. Journal of Athletic Training, 42, 303-310.

Andersen, M. B., \& Williams, J. M. (1988). A model of Stress and Athletic Injury: Prediction and Prevention. Journal of Sport \& Exercise Psychology, 12, 294-306. https://doi.org/10.1123/jsep.10.3.294

Artioli, G. G., Gualano, B., Franchini, E. et al. (2009). Physiological, Performance, and Nutritional Profiles of the Brazilian Olympic Wushu (Kung Fu) Team. Journal of Strength and Conditioning Research, 23, 20-25. 
https://doi.org/10.1519/JSC.0b013e318187687a

Artioli, G. G., Gualano, B., Francini, E. et al. (2010). Prevalence, Magnitude, and Methods of Rapid Weight Loss among Judo Competitors. Medicine \& Science in Sports \& Exercise, 42, 436-442. https://doi.org/10.1249/MSS.0b013e3181ba8055

Barrault, D., Achou, B., \& Sorel, R. (1983). Accidents et incidents survenus au cours des compétitions de judo. Symbian, 41, 144-152.

Birrer, R. B., \& Halbrook, S. P. (1988). Martial Arts Injuries: The Results of a 5-Year National Survey. American Journal of Sports Medicine, 16, 408-410. https://doi.org/10.1177/036354658801600418

Boisseau, N. (2006). Consequences of Sport-Imposed Weight Restriction in Childhood. Ann Nestlé, 64, 77-84. https://doi.org/10.1159/000093014

Brooks, C. P., Woodruff, L. D., Wright, L. L., \& Donatelli, R. (2005). The Immediate and Effects of Manual Massage on Power-Grip Performance after Maximal Exercise in Healthy Adults. The Journal of Alternative and Complementary Medecine: Research on Paradigm, Practice, and Policy, 11, 1093-1101.

https://doi.org/10.1089/acm.2005.11.1093

Brito, C. L., Castro Martins Roas A. F., Souza Brito I. S. et al. (2012). Methods of BodyMass Reduction by Combat Sport Athletes. International Journal of Sport Nutrition and Exercise Metabolism, 22, 89-97. https://doi.org/10.1123/ijsnem.22.2.89

Campos, F. A., Bertuzzi, R., Dourado, A. C. et al. (2012). Energy Demands in Taekwondo Athletes during Combat Simulation. European Journal of Applied Physiology, 112, 1221 1228. https://doi.org/10.1007/s00421-011-2071-4

Cunningham, S. (1996). Injury Surveillance at a National Multisport Event. Australian Journal of Science and Medicine in Sport, 28, 50-56.

Cynarski, W. J., \& Kudlacz, M. (2008). Injuries in Martial Arts and Combat Sport: A Comparative Study. Archives of Budo, 4, 91-97.

Del Vecchio, F. B., Hirata, S. M., \& Franchini, E. (2011). A Review of Time-Motion Analysis and Combat Development in Mixed Martial Arts Matches at Regional Level Tournaments. Perceptual and Motor Skills, 112, 639-648.

https://doi.org/10.2466/05.25.PMS.112.2.639-648

Del Veccio, F. B., \& Gonçalves, A. (2012). Descriptive Epidemiology of Sports Injuries. Revista Brasileira de Medicina do Esporte, 69, 323-327.

Deroche, T., Stephan, Y., Woodman, T. et al. (2012). Psychological Mediators of the Sport Injury-Perceived Risk Relationship. Risk Analysis, 32, 113-121.

https://doi.org/10.1111/j.1539-6924.2011.01646.x

Engebresten, L., Soligard, T., Steffen, K. et al. (2013). Sports Injuries and Illnesses during the London Summer Olympic Games 2012. British Journal of Sports Medicine, 47, 407414. https://doi.org/10.1136/bjsports-2013-092380

Fabrini, S. P., Brito, C. J., Mendes E. L. et al. (2010). Práticas de Redução de Massa Corporal em Judokcas Nos Periodos Pré-Competitivos. Revista Brasileira de Educação Física e Esporte, 24, 165-177. https://doi.org/10.1590/S1807-55092010000200002

Franchini, E., Del Vecchio, F. B., Matsushigue, K. A. et al. (2011). Physiological Profiles of Elite Judo Athletes. Sports Medicine, 41, 147-166.

https://doi.org/10.2165/11538580-000000000-00000

Green, C. M., Petrou, M. J., Fogarty-Hover, M. L. et al. (2007). Injuries among Judokas during Competition. Scandinavian Journal of Medicine \& Science in Sports, 17, 205210.

Gutiérrez-Garcia, C., Pérez Gutiérez, M., \& Svinoh, J. (2010). Martial Arts of the Word. 
An Encyclopedia of History and Innovation. California ABC-Clio, Santa Barbara, 1, 181187.

Harmer, P. A. (2010). Judo. In D. J. Caine, P. A. Harmer, \& M. A. Schiff (Eds.), Epidemiology of Injury in Olympic Sport (pp. 161-175). Oxford: Wiley Blackwell.

James, G., \& Pieter, W. (2003). Injury Rates in Adult Elite Judoka. Biology of Sport, 20, 2532.

Junge, A., Engebretsen, L., Mountjoy, M. L. et al. (2009). Sports Injuries during the Summer Olympic Games 2008. American Journal of Sports Medicine, 37, 2165-2172. https://doi.org/10.1177/0363546509339357

Kobayashi, H., Kanamura, T., Koshida, S. et al. (2010). Mechanics of the Anterior Cruciare Ligament Injury in Sports Activoties: A Twenty-Year Clinical Research of 1700 Athletes. Journal of Sports Science and Medicine, 9, 669-675.

Kordi, R., Maffulli, N., Wroble, R. et al. (2009). Combat Sports Medecine (pp. 21-40). London: Springer.

Ogai, R., Yamane, M., Matsumoto, T., \& Kosaka, M. (2008). Effects of Petrissage Massage on Fatigue and Exercise Performance Following Intensive Cycle Pedalling. British Journal of Sports Medecine, 42, 834-838. https://doi.org/10.1136/bjsm.2007.044396

Pierantozzi, E., \& Muroni, R. (2009). Judo High Level Competitions Injuries. Mediterranean Journal of Muscular Survey, 17, 26-29.

Pieter, W. (2005). Martial Arts Injuries. Journal of Science and Medicine in Sport, 48, 5973. https://doi.org/10.1159/000084283

Poceco, E., Ruedl, G., Stankovic, N. et al. (2013). Injuries in Judo: A Systematic Literature Review Including Suggestions for Prevention. British Journal of Sports Medicine, 47, 1139-1143. https://doi.org/10.1136/bjsports-2013-092886

Poutreau, S., Pelle, A., Collomp, K. et al. (2006). Bone Density in Elite Judoists and Effects of Weight Cycling on Bone Metabolic Balance. Medicine \& Science in Sports \& Exercise, 38, 694-700. https://doi.org/10.1249/01.mss.0000210207.55941.fb

Poutreau, S., Ducher, G., Serbescu, C., Zemper, E., \& W. Pieter (2007). Incidence and Nature of Judo Injuries. In: F. H. Fu, \& D. A. Stone (Eds.), Sports Injuries Mechanics, Prevention, Treatment (pp. 715-733). Baltimore: Williams \& Wilkins.

Rivera-Brown, A. M., \& De Felix-Davila, R. A. (2012). Hydration Status in Adolescent Judo Athletes before and after Training in the Heat. International Journal of Sports Physiology and Performance, 7, 39-46. https://doi.org/10.1123/ijspp.7.1.39

Souza, M., Monteiro, H., Del Vecchio, F. et al. (2006). Referring to Judo's Sports Injuries in Sao Paulo State Championship. Science \& Sports, 21, 280-284.

https://doi.org/10.1016/j.scispo.2006.06.002

Souza, M., \& Monteiro, M. (2006). Referring to Judo's Injuries in Sao Paulo State Championship. Science \& Sports, 21, 280-284.

https://doi.org/10.1016/j.scispo.2006.06.002

Sterkowicz, S. (1999). Body Injuries of Young Training in Judo. http://www.judoinfo.com/research4.htm

Travagli, V., Zanardi, L., Valacchi, G., \& Bocci, V. (2011). Ozone and Ozonated Oil in Skin Diseases: A Review. Mediators of Inflammation, 2010, Article ID: 610418.

Terbizan, D. J., \& Selievold, P. J. (1996). Physiological Profile and Age-Group Wrestlers. Journal of Sports Medicine and Physical Fitness, 36(3), 178-185.

Vago, P., Casola, F., Lovecchio, N. et al. (2013). Anxiety and Injuries in Soccer Players. British Journal of Sports Medicine, 47, e3. https://doi.org/10.1136/bjsports-2013-092558.86 
Witkowski, K., Maslinski, J., Stefaniak, T. et al. (2012). Causes of Injuries in Young Female Judokas. Archives of Budo, 8, 109-116. https://doi.org/10.12659/AOB.883027

Yard, E. E., \& Knox, C. L. (2007). Pediatric Martial Arts Injuries Presenting to Emergency Departments. United States 1990-2003. Journal of Science and Medicine in Sport, 10, 219-226. https://doi.org/10.1016/j.jsams.2006.06.016

\section{Scientific Research Publishing}

Submit or recommend next manuscript to SCIRP and we will provide best service for you:

Accepting pre-submission inquiries through Email, Facebook, LinkedIn, Twitter, etc. A wide selection of journals (inclusive of 9 subjects, more than 200 journals)

Providing 24-hour high-quality service

User-friendly online submission system

Fair and swift peer-review system

Efficient typesetting and proofreading procedure

Display of the result of downloads and visits, as well as the number of cited articles Maximum dissemination of your research work

Submit your manuscript at: http://papersubmission.scirp.org/

Or contact ape@scirp.org 